\title{
PROPOSAL PROYEK \\ SISTEM INFORMASI ONLINE STORE MIX DISTRO \\ ( BERBASIS WEB )
}

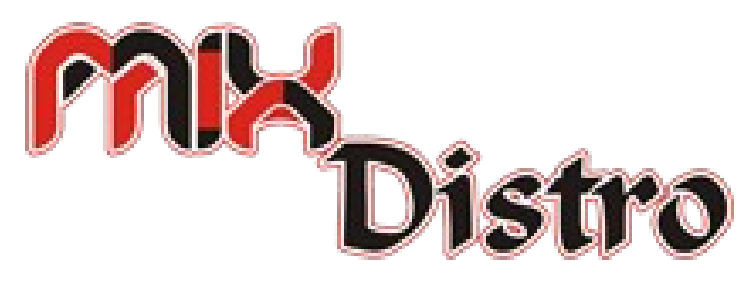

\author{
NAMA : FADLI SINAGA \\ NIM : 0702203104 \\ KELAS : SISTEM INFORMASI-4
}

MATA KULIAH : SISTEM INFORMASI MANAJEMEN DOSEN PENGAMPU : Dr.YAHFIZAM, S.T., M.Cs

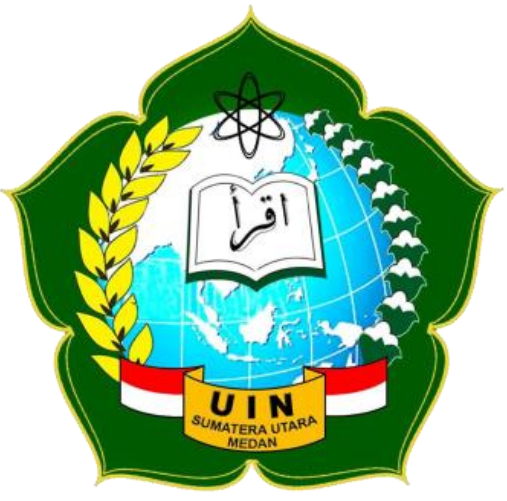

FAKULTAS SAINS DAN TEKNOLOGI UNIVERSITAS ISLAM NEGERI SUMATERA UTARA 2021 


\section{A. Latar Belakang}

Di dalam sebuah perkembangan di dunia informasi dari waktu ke waktu masih mengalami peningkatan maupun perkembangan. Karena itu dapat di dukung dalam perkembangan Teknologi yang semakin maju dan memadai. Sampai kini Informasi dapat diakses dengan cepat, tepat, terkini, dan sangat akurat. Selain itu untuk menarik costumer untuk mendapat sebuah perhatian yang srius pada suatu informasi.

Pada MIX Distro yaitu sebuah usaha yang bergerak di dalam suatu bidang konveksi dan style. Permasalahan masyarakat yang timbul yang mengakibatkan promosi dan informasi menggunakan brosur dan pamphlet. Kelemahan pada perusahaan adalah penyampaian informasi tentang produk-pruduk yang di pasarkan kepada masyarakat. Kurang nya waktu luang membuat perusahaan kurang optimal di karenakan costumer tidak bisa datang langsung membeli ke toko, sehingga pembeli memilih perusahaan lain.

Dengan adanya permasalahan inilah penulis membuat desain website sebagai untuk mengoptimalkan dalam mempromosikan bagi MIX Distro. Perusahaan hanya dapat mempromosikan produk tetapi website ini juga dapat memesan secara online dengan mengirim data dan gambar melalui website. Dengan menggunakan PHP, dan MySql maka Penulis memberikan solusi dengan membuat website secara online pada MIX Distro. Yang dapat memudahkan costumer untuk memesan secara online dengan desains website diharapkan dapat membantu dan meningkatkan sebuah informasi.

\section{B. Rumusan Masalah}

Adanya Permasalahan yang telah di sampaikan diatas Rumusan masalah yang penulis Ajukan adalah "Bagaimana cara membuat desain web sebagai media informasi pemesanan pada MIX Distro dengan Menggunakan, MySql. Untuk mengambil sebuah keputusan dalam mendapatkan data / informasi yang bermanfaat dari internal maupun eksternal yang membantu secara eksekutif.

\section{Ruang Lingkup}


Untuk memudahkan dalam pengumpulan data dan penulisan proposal proyek ini maka perlu adanya pokok pembahasan sebagai berikut :

1. Contoh- contoh Produk

2. Pemesanan

3. Pembayaran

4. Pelaporan customer

\section{Tujuan \& Manfaat Tujuan}

1. Tujuan pokok

Tujuan utama dari Tugas Proyek ini adalah mendesign system informasi berbasis web dengan menggunakan php, dan mysql pada MIX Distro guna memudahkan pemesanan produk.

\section{Tujuan Eksekutif}

Secara internal maupun eksternal untuk mendapatkan data dan informasi-informasi yang baik dalam mempermudah tujuan eksekutif. Untuk membantu proses bisinis yang akan di jalankan seperti contoh : produk, pemesanan, pembayaran, dan laporan aktifitas bisnis.

3. Manfaat

- pelanggan dalam memesan produk / order

- Memperluas wilayah usaha

- Memudahkan dalam promosi MIX Distro

\section{E. Metodologi}

Dengan adanya Proyek “Aplikasi Sistem Informasi Toko Online Berbasis Web” merupakan elemen yang mendasar dari sebuah proses bisnis dalam merealisasikan proyek. Dan langkahlangkah yang akan di tempuh sebagai berikut:

\section{Studi Kelayakan}

Dalam hal ini Eksklusif Untuk meningkatkan pelayanan efisiensi dan Keputusan dalam perancangan “Aplikasi Sistem Informasi Toko Online Berbasis Web” sehingga dapat membantu kebutuhan perusahaan merupakan sebuah proses-proses identifikasi data-data yang dibutuhkan. 


\section{Desain Fungsi}

Fungsi-fungsi bisnis yang akan di lakukan dengan desain sistem secara detail, mulai dari Flowchart, Data, Flow Diagram (DFD), dan desain tabel, sehingga dapat membentuk sistem yang lengkap.

\section{Pemrograman}

Fungsi yang telah dibuat dalam melakukan coding untuk dapat merealisasikan desain. Besar / Kecil nya harga Aplikasi yang dibuat merupakan lama pengerjaan dan jumlah baris coding ini yang turut menentukan.

\section{Black Box Testing}

1. Uji Prilaku (behavior testing)

2. Focus input / output

3. Fungsionalitas

\section{Pelatihan}

Untuk mengoperasikan sebuah program aplikasi yang telah dibuat sebelum dijalankan/ kunjungi oleh user, pihak developer proyek perangkat lunak yang bertanggung jawab untuk melatih costumer atau Ekseskutif dari MIX Distro. Tidak menyulitkan para pengguna merupakan kewajiban pihak pengembang memberikan informasi benar dan terbuka.

\section{Pemeliharan}

Untuk beroperasi dengan baik dan tidak terkendala proyek perangkat lunak tidak bisa selesai begitu saja setelah si serahterimakan, tetapi masih berlanjut ke tahap hingga tenggang waktu yang cukup untuk memastikan bahwa produk perangkat lunak yang telah diserahkan harus berjalan dengan lancar dan baik, tidak ada masalah lagi. 
Sebagai pedoman operasional Dokumen dibuat untuk melihat kemajuan proyek yang sedang di kembangkan, sebagai referensi untuk bug bila terjadi kendala, dalam sebuah proyek yang terdiri dari beberapa dokumen.

\section{F. Waktu Pelaksanaan Proyek :}

\begin{tabular}{|c|c|c|c|c|c|c|c|c|c|c|c|c|}
\hline \multirow{2}{*}{$\begin{array}{l}\text { Kegiatan \&Waktu } \\
\text { Pulakxanazt }\end{array}$} & \multicolumn{4}{|c|}{ Dessmbir } & \multicolumn{4}{|c|}{ lanusi } & \multicolumn{4}{|c|}{ Estruani } \\
\hline & 1 & 2 & 3 & 4 & 1 & 2 & 3 & 4 & 1 & 2 & 3 & 4 \\
\hline Shaty kelaysakan & & & & & & & & & & & & \\
\hline Desiz̨n lunģi & & & & & & & & & & & & \\
\hline Peinregaman & & & & & & & & & & & & \\
\hline Pengugian & & & & & & & & & & & & \\
\hline Pelatifin & & & & & & & & & & & & \\
\hline Pemelikarian & & & & & & & & & & & & \\
\hline Dodumentios & & & & & & & & & & & & \\
\hline
\end{tabular}

\section{G. Angaran Biaya Biaya Persiapan :}

Tipe

Requitment Spesifikasi Pengembangan
S
Macromedia
2.
My
Domain \&
190.0

\begin{tabular}{|c|c|c|}
\hline & 1 Paket Komputer (PC) & 4.999 .000 \\
\hline & Modem Eksternal & 1.200 .000 \\
\hline Hardwere & 1 Printer & 750.000 \\
\hline
\end{tabular}




\begin{tabular}{lll}
\hline No. & Perincian & Biaya \\
\hline 1 & Studi Kelayakan & 300.000 \\
\hline 2 & Design Fungsi & 400.000 \\
\hline 3 & Pemrograman & 2.000 .000 \\
\hline 4 & Pengujian & 250.000 \\
\hline 5 & Pelatihan & 200.000 \\
\hline 6 & Pemcliharaan & 300.000 \\
7 & Dokumentasi & 200.000 \\
\hline 8 & Biaya Lainnya & 300.000 \\
\hline & Jumlah & 3.950 .000 \\
\hline
\end{tabular}

\section{Biaya Pengerjaan :}

\section{H. Sumber Daya Manusia}

Sumber daya manusia yang melaksanakan proyek “Aplikasi Sistem Informasi Toko

Online Berbasis Web" adalah sebagai berikut :

No Nama Peran :

1. Fadli Sinaga Manager Proyek, Studi Kelayakan, Dokumentasi

2. Zulus Ichrom Ai. Programer, Testing, Pemeliharaan

3. Imron Asy' ari Desain Fungsi, Design Interface, Pelatihan

\section{Penutup}

Demikian lah proposal penawaran jasa website ini saya buat. Semoga proposal ini dapat diterima dan dapat bermanfaat bagi kita semua. Tidak lupa saya ucapkan puji dan syukur kepada Allah swt. Karena atas segala rahmat dan hidayah-Nya saya dapat menyelesaikan proposal penawaran ini.

Atas segala waktu dan perhatiannya saya ucapkan terimakasih.

Wassalamualaikum warahmatullahi wabarakatuh. 